African Journal of Biomedical Research, Vol. 11 (2008); 339 - 342

Full-text available at http://www.ajbrui.com http://www.bioline.br/md http://www.ajol.com

Received:

April 2008

Accepted (Revised): August 2008

Published

September 2008
Short communication

\section{Arthropods Associated with Mammalian Carcasses in Rivers State, Nigeria.}

\section{${ }^{1 *}$ Okiwelu S.N,. ${ }^{2}$ Ikpamii T, ${ }^{3}$ Umeozor O.C.}

Department of Animal and Environmental Biology, Faculty of Science, University of Port Harcourt, Port Harcourt, NIGERIA.

E-mail: okiwelu2003@yahoo.com

\section{ABSTRACT}

A total of 281 insects in four families of 2 orders: Diptera (Muscidae, Syrphidae, Calliphoridae) and Hymenoptera (Adidae), and 2 ixodids were collected from the mona monkey, Cercipithecus mona. The major species was the house fly, Musca domestica (72\%). The entomofauna from the Giant cane Rat, Thyronomys swinderianus carcass, totalled 257 in 3 families of 2 orders: Diptera (Muscidae, Syrphidae) and Hymenoptera (Formicidae). The dominant species was $M$. domestica $(76 \%)$. The highest insect population was 414 , recorded from the carcass of the Forest Genet, Genetta poensis; it consisted of 5 families in 3 orders: Diptera (Muscidae, Bombyliidae, Syrphidae), Coleoptera (Cleridae) and Hemiptera (Reduviidae). The order Diptera was dominant on all carcasses and the most prominent dipteran $M$. domestica was collected continuously, while the appearance of the other species was sporadic. Complete decomposition period was shortest (11 days) in the Giant cane Rat and longest (44 days) in the forest genet; the period in the mona monkey was 14 days. Successional occurrence of these arthropods was not discernible. These results are compared to those from other studies.

(Afr. J. Biomed. Res. 11: 339 - 342)

Key Words: Arthropods, Mammals, Carcasses.

*Corresponding Author

Abstracted by:

African Index Medicus (WHO), CAB Abstracts, Index Copernicus, Global Health Abstracts, Asian Science Index, Index

Veterinarius, Bioline International, African Journals online 


\section{INTRODUCTION}

Forensic entomology is the use of the knowledge of insects in investigations of crimes or even civil disputes; it also includes the application of the study of insects and other arthropods to legal issues, especially in a court of law. Forensic entomology is divided into 3 sub-fields: Urban Forensic entomology, stored products forensic entomology and medico-legal (medico-criminal) forensic entomology. The aspect of emphasis worldwide is the medico-legal forensic entomology which has to do with arthropod involvement in events surrounding felonies or serious crimes; these are usually violent crimes like rape, suicide, murder and other aspects of crime, such as physical abuse and contraband trafficking. (Keh, 1985; Catts and Goff, 1992). The most common application of the medico-legal category relates to death investigations and the essentials are: the time since death, which is PostMortem Interval (PMI), manner and cause of death and association of suspects with the death scene; these relate to the occurrence and activity of arthropods.

Surprisingly, the basic concept of forensic entomology has not been applied to wildlife conservation, by targeting poachers in wildlife parks and forest reserves and hunters involved in the indiscriminate slaughter of endangered species for commerce. In Nigeria, this is with particular reference to the Endangered (International Trade and Traffic) Species, Decree No 11 of 1985. There have been a number of published studies over the past decades on arthropods in decomposing carrion (Fuller, 1934; Mohr, 1943; Norris, 1965; Payne and King, 1970; Keh, 1985), but none from Nigeria. Furthermore, most of these were on pigs (Payne, 1965; Payne and King, 1970; Payne and Mason, 1971).

Preliminary studies were undertaken to determine the arthropods associated with three wildlife carcasses: the rodent, Giant cane Rat (Thyronomys Swinderianus); the carnivore, forest genet (Genetta poensis) and the primate, Mona monkey (Cercopithecus mona).

\section{MATERIALS AND METHODS}

The Mona monkey, forest genet and Greater Cane rat were purchased immediately after delivery at the Omagwa bushmeat market, $6.9172^{\circ} \mathrm{E}$ and $4,9827^{\circ} \mathrm{N}$, the major bushment centre in Rivers State, located on the busy Port Harcourt-Owerri interstate road' and transported without delay to the University of Port Harcourt, approximately $20 \mathrm{~km}$, southwest of Omagwa.

They were placed in separate cages, constructed of mesh wire, at the University's Botanical Garden to prevent predators from devouring the animals, Insects arriving at the carcasses placed $50 \mathrm{~m}$ apart, were collected with hand net at 3-hourly intervals, $0600-1800 \mathrm{hr}$ in the first 3 days. Subsequent collections were on a daily basis until complete skeletonization of the carcasses. Ticks were collected with a pair of forceps. Collected arthropods were preserved in $70 \%$ alcohol and subsequently identified. Type specimens in the Insect Museum at the University of Port Harcourt were used for the identification.

\section{RESULTS}

A total of 281 insects in 3 families (Adidae, Muscidae, Syrphidae, Calliphoridae) of the Diptera and 1 family (Adidae) of the Hymenoptera were collected between death and the complete skeletonizaion of the Mona monkey. Two specimens of Arachnids in the order Ixodidae were also recorded. The dominant species was the common housefly, Musca domestica; it constituted approximately $72 \%$ (Table 1), M. domestica was recorded daily over a 14-day period, while Eristalis quinqualineatus occurred continuously for the first 10 days. The appearance of the other species was sporadic (Fig 1).

The arthropod community from the carcass of the Giant Cane Rat was restricted to insects in two families (Musidae, Syrphidae) of the Diptera, and one family (Formicidae) of the Hymenoptera. A total of 257 insects were recorded. The dominant species was $M$. domestica, constituting $72 \%$ of the collections, while E. quinquelineatus was $24 \%$ (Table 2), M. domestica appeared continuously throughout the 11-day period, from the display of fresh carcass to complete skeletonization. 
Table 1:

Species Composition and Abundance of Arthropods from the Mona Money Cercoptitiiecus Mona, Carcass

\begin{tabular}{|c|c|c|c|c|c|}
\hline Phylum & Class & Order & Family & Species & Abundance \\
\hline Arthropoda & Insecta & Diptera & Muscidae & Musca sorbents & 20 \\
\hline “ & “" & " & “" & Musa domestica & 203 \\
\hline " & “" & “ & Calliphoridae & $\begin{array}{l}\text { Chrysomyia } \\
\text { chloropyga }\end{array}$ & 9 \\
\hline “ & “ & " & syphidae & $\begin{array}{l}\text { Eristalis } \\
\text { quinquelineatus }\end{array}$ & 48 \\
\hline & & & Adidae & Megachile cineta & 1 \\
\hline & & & Ixodidae & $\begin{array}{l}\text { Ablyomma } \\
\text { Herbraeum }\end{array}$ & 2 \\
\hline \multicolumn{5}{|l|}{ TOTAL } & 283 \\
\hline
\end{tabular}

TABLE 2:

Species Composition and Abundance of Arthropods Collected From the Giant Cane Rat, Thyronomys Swinderianus, Carcass

\begin{tabular}{|l|l|l|l|l|l|}
\hline Phylum & Class & Order & Family & Species & Abundance \\
\hline Arthropoda & Insecta & Diptera & Muscidae & Musca domestica & 185 \\
\hline “ & “ & " & " & Helina prompinqua & 3 \\
\hline “ & " & “ & “ & Stomoryx nigra & 2 \\
\hline & Hymenoptea & Formicidae & $\begin{array}{l}\text { Myremecaria } \\
\text { senainquelineatus }\end{array}$ & 60 \\
\hline TOTAL & \multicolumn{3}{|l|}{1} \\
\hline
\end{tabular}

TABLE 3:

Species Composition and Abundance of Arthropods Collected From the Forest Genet, Genetta Poensis, Carcass

\begin{tabular}{|c|c|c|c|c|c|}
\hline Phylum & Class & Order & Family & Species & Abundance \\
\hline Arthropoda & Insecta & Diptera & Muscidae & Musca domestica & 309 \\
\hline “ & “" & “" & “ & Stomoryx nigra & 11 \\
\hline “ & “" & " & “" & Haematobia minuta & 1 \\
\hline \multirow[t]{6}{*}{ “ } & "“ & “" & “" & Helina propinqua & 2 \\
\hline & & & & Artherigona aberans & 1 \\
\hline & & & Bombylidae & Bombylius analis & 1 \\
\hline & & & Syrphidae & $\begin{array}{l}\text { Eristalis } \\
\text { us } \quad \text { quinquelineat }\end{array}$ & 67 \\
\hline & & Coleoptera & Cleridae & Necrobia ruficollis & 21 \\
\hline & & Hemiptera & Reduviidae & Coranus Metallicus & 1 \\
\hline TOTAL & & & & & 414 \\
\hline
\end{tabular}

The appearance of other species was discontinuous (fig 2).

A total of 414 insects in 5 families of three orders: Diptera (Muscidae, Bombyliidae,
Syphiidae); coleopteran (Cleridae) and Hemiptera (Reduviidae) were collected from the Forest Genet. M. domestica was dominant (78\%) (Table 3). M. domestica was collected daily throughout 
the 25-day period, from the display of fresh carcass to complete skeletonization; the appearance of other species was discontinuous (Fig 3).

\section{DISCUSSION}

Keh (1985) classified arthropods in corpses and carcasses according to their roles: predators and parasitoids, necrophages, cryptozoics. Predators and parasitoids are arthropods that prey and rely on others. These comprise a very mixed group of arthropods, whose potential for forensic information has not been well studied. Necrophages are species that feed on corpse or carcass tissue. They appear successively in correspondence to changes in carcasses and corpses; the most significant ones are the blowflies. Arthropods that shelter in, on or under carcasses and corpses are best categorized as cryptozoics. Little is known about their potential in providing useful forensic information (Keh, 1985).

Species richness and abundance were highest in the carcass of the forest genet; this was probably related to the longer period ( 25 days) of decomposition, compared to 11 and 14 days for the Greater Cane rat and Mona monkey respectively. The arthropod fauna on all carcasses were dominated by necrophages, specifically dipterans (syrphids, muscids) and coleopterans (clerids); The Calliphorid Chrysomyia chloropyga was only recorded on the primate, Mona monkey, the closest relative to humans, Homo sapiens, among the three experimental animals. This observation is noteworthy because Catts and Goff (1992) observed the early appearance of calliphorids and sarcophagids on corpses. The current results are at variance with those on pigs, where coleopterans and dipterans (Calliphorids and Sarcophagids) were dominant (Payne, 1965; Payne and King, 1970; Payne and Mason, 1971). The formicoid, Myremecaria senaarensis and larvae of the Bombyliid, Bombylius analis and Reduviid, Coranus metallicus were predators. Successional occurrence of these arthropods was not discernible.

\section{ACKNOWLEDGEMENT}

The authors greatly thank Mrs. E. Udoetuk for technical assistance during period of investigation and The Director General, Nigerian Institute for Trypanosimasis Research for providing the funds.

\section{REFERENCES}

Barshop Catts, E.P. \& Goff, M.L. (1992): Forensic Entomology in Criminal Investigations. Anual Rev. Entomol. 37: $253-272$.

Fuller, M.E. (1934): The Insect Inhabitants of Carrion: A Study in Animal Ecology. Aust. Counc. Sci. Ind. Res. Bull. No. 82. 62 pp.

Keh, B. (1985): Scope and Applications of Forensic Entomology. Ann. Rev. Entomol. 30:137 - 154

Mohr, C. O. (1943): Cattle Droppings as ecological units. Ecol. Monogr. 13: 277 - 98.

Norris, K.R. (1965): The bionomics of blow files. Ann. Rev. Entomol 10:47 - 68

Payne, J. A. 1965. A Summer Carrion Study of the baby pig, Sui scrofa Linnacus. Ecology 46: 592 -602 .

Payne J.A. \& King E. W. (1970). Coleoptera Associated with pig carrion. Entomol. Mon. Mag. 105:224 - 32 .

Payne, J. A. \& Mason, W.R. M. (1971): Hymenoptera Associated with pig. Carrion. Proc. Entomol. Soc. Wash. 73:132 - 41 . 